\title{
Quantitative analysis and anti-inflammatory effects of Gleditsia sinensis thorns in RAW 264.7 macrophages and HaCaT keratinocytes
}

\author{
CHANG-SEOB SEO ${ }^{1 *}$, HYE-SUN LIM ${ }^{1,2^{*}}$, HYEKYUNG HA ${ }^{1}$, SEONG EUN JIN ${ }^{1}$ and HYEUN-KYOO SHIN ${ }^{1}$ \\ ${ }^{1}$ K-herb Research Center, Korea Institute of Oriental Medicine, Daejeon 305-811; \\ ${ }^{2}$ Center for Biomedical Science, Division of Allergy and Chronic Respiratory Diseases, \\ National Institute of Health, Cheongju, Chungbuk 361-951, Republic of Korea
}

Received August 28, 2014; Accepted May 29, 2015

DOI: $10.3892 / \mathrm{mmr} .2015 .3936$

\begin{abstract}
Gleditsia sinensis thorns have traditionally been used to treat edema and carbuncles and drain abscesses. In the present study, a simultaneous analysis of four flavonoids [(+)-catechin,(-)-epicatechin, eriodictyol and quercetin] and two phenolic compounds (caffeic acid and ethyl gallate), obtained from a $70 \%$ ethanol extract of $G$. sinensis, was performed using high-performance liquid chromatography-photodiode array techniques. In addition, the inhibitory activities of the solvent fractions from a $G$. sinensis extract and its major constituents on the lipopolysaccharide-stimulated production of inflammatory mediators by macrophage RAW 264.7 cells and the tumor necrosis factor (TNF)- $\alpha$ and interferon (IFN)- $\gamma$ (TI)-stimulated production of chemokines by HaCaT keratinocyte cells were investigated. The established analytical method showed high linearity, with a correlation coefficient of $\geq 0.9998$. The limits of detection and quantification of the six compounds were 0.037-0.425 and 0.124-1.418 $\mu \mathrm{g} / \mathrm{ml}$, respectively. The ethyl acetate fraction inhibited nitric oxide and prostaglandin $\mathrm{E}_{2}$ production in RAW 264.7 cells and the production of thymus- and activation-regulated chemokine (TARC) in HaCaT cells more than did the other fractions. Furthermore, the six compounds reduced the production of TARC, macrophage-derived chemokine and regulated on activation normal T-cell expressed and secreted in TI-stimulated HaCaT cells; in particular, ethyl gallate and quercetin exhibited a significant dose-dependent inhibition. Further elucidation of the signaling pathways involved in the T-helper cell 2
\end{abstract}

Correspondence to: Dr Hyeun-Kyoo Shin, K-herb Research Center, Korea Institute of Oriental Medicine, 483 Expo-ro, Daejeon 305-811, Republic of Korea

E-mail: hkshin@kiom.re.kr

"Contributed equally

Key words: Gleditsia sinensis, macrophage, high-performance liquid chromatography, anti-inflammatory, keratinocyte chemokine inhibition by $G$. sinensis is necessary to facilitate the design of therapeutic agents for the inflammatory response.

\section{Introduction}

The inflammatory response is a complex reaction of the immune system that is regulated by numerous inflammatory mediators, such as nitric oxide (NO), cytokines/chemokines and prostaglandins (1). These mediators are known to contribute to the regulation of a wide array of physiological and pathological processes following an immune response and inflammation $(1,2)$. The role of macrophages in mediating numerous different immunopathological phenomena during inflammation, including the overproduction of inflammatory cytokines and mediators, such as tumor necrosis factor- $\alpha$ (TNF- $\alpha$ ), interleukin (IL)-1 $\beta$, IL-6, NO and prostaglandin $\mathrm{E}_{2}$ $\left(\mathrm{PGE}_{2}\right)$ is crucial. NO is synthesized by inducible NO synthase (iNOS), and $\mathrm{PGE}_{2}$ is synthesized by cyclooxygenase-2 (COX-2) $(3,4)$.

Inflammatory chemokines play a fundamental role in attracting a diverse set of effector leukocytes to sites of inflammation (5). Various chemokines have been shown to affect the immunopathology of inflammatory skin diseases. The thymus- and activation-regulated chemokine (TARC/CCL17) has been shown to be upregulated by keratinocytes in atopic dermatitis lesional skin (6); therefore, the modulation of TARC production in keratinocytes may contribute to the pathological processes of inflammatory skin diseases, such as atopic dermatitis. The serum level of the macrophage-derived chemokine (MDC/CCL22) has been reported to be significantly elevated in patients with atopic dermatitis, and increased levels of these chemokines were associated with increased disease severity (7). Furthermore, enhanced production of regulated upon activation normal T-cell expressed and secreted (RANTES/CCL5) has been found in inflammatory diseases of the skin, including atopic dermatitis and psoriasis (8).

The thorns of Gleditsia sinensis (Leguminosae) are widely used in traditional Chinese and Korean medicine for the treatment of several diseases, including tumor-related diseases, obesity and thrombosis (9). Previous studies have investigated the biological activity of the chemical constituents of 
G. sinensis thorns, such as stigmasterol (10), ellagic acid glycosides (11), flavonoids (12) and lupane acid (13); however, the anti-inflammatory effects of $G$. sinensis thorn extracts remain unclear. The aim of the present study, therefore, was to investigate the anti-inflammatory activities of the solvent fractions from a $G$. sinensis extract and its major constituents on the lipopolysaccharide (LPS)-stimulated production of inflammatory mediators by RAW 264.7 macrophages and the TNF- $\alpha$ and IFN- $\gamma$ (TI)-stimulated production of chemokines by $\mathrm{HaCaT}$ keratinocytes.

\section{Materials and methods}

Plant material. Thorns of G. sinensis were purchased in October 2008 from Omniherb (Yeongcheon, Republic of Korea). The origin of these materials was confirmed taxonomically by Professors Je-Hyun Lee (Dongkuk University, Gyeongju, Republic of Korea) and Young-Bae Seo (Daejeon University, Daejeon, Republic of Korea). A voucher specimen (2008-ST22) has been deposited at the K-herb Research Center, Korea Institute of Oriental Medicine (Daejeon, Republic of Korea).

Extraction and solvent fractionation. The dried thorns of $G$. sinensis (10 kg) were extracted three times with $70 \%$ ethanol by sonication for $1 \mathrm{~h}$. The extracted solution was filtered through filter paper and evaporated to dryness (450 g). The ethanol extract was suspended in water (1 liter) and then successively partitioned with $n$-hexane, ethyl acetate and $n$-butanol (1.5 liters each, three times) to give extracts of 33.8 , 103.2 and $119.1 \mathrm{~g}$, respectively.

Chemicals and reagents. (-)-Epicatechin, ethyl gallate and quercetin (all with purity $\geq 99.0 \%$ ) were purchased from ChromaDex, Inc., (Santa Ana, CA, USA). Caffeic acid, eriodictyol and (+)-catechin (all with purity $\geq 99.0 \%$ ) were obtained from Acros Organics (Fair Lawn, NJ, USA), Extrasynthèse S.A. (Genay, France) and Fluka AG (Buchs, Switzerland), respectively. Methanol, high-performance liquid chromatography (HPLC)-grade reagents, water and acetonitrile were purchased from J.T. Baker Chemical Co. (Phillipsburg, NJ, USA). Glacial acetic acid was of analytical reagent grade and was procured from Junsei Chemical Co. (Tokyo, Japan).

Chromatographic conditions. This analysis was performed using a Shimadzu LC-20A HPLC system (Shimadzu Co., Kyoto, Japan), which consisted of an on-line degasser, a solvent-delivery unit, an autosampler, a photoiode array (PDA) detector and a column oven. The data processor employed the LC solution software (version 1.24; Shimadzu Co.). A Gemini ${ }^{\circledR}$ C18 analytical column $(250 \times 4.6 \mathrm{~mm}$; particle size $5 \mu \mathrm{m}$; Phenomenex, Torrance, CA, USA) was used. Solvent A (1.0\%, $\mathrm{v} / \mathrm{v}$, aqueous acetic acid) and solvent B (acetonitrile with $1.0 \%$, $\mathrm{v} / \mathrm{v}$, acetic acid) comprised the mobile phases. The gradient flow was as follows: $0-50 \mathrm{~min}, 5-70 \%$ solution B; 50-55 min, $70-100 \%$ solution $\mathrm{B}$; $55-60 \mathrm{~min}, 100 \%$ solution $\mathrm{B}$; $60-65 \mathrm{~min}$, $100-105 \%$ solution $\mathrm{B}, 65-80 \mathrm{~min}, 5 \%$ solution $\mathrm{B}$. The column temperature was maintained at $40^{\circ} \mathrm{C}$. The analysis was carried out at a flow rate of $1.0 \mathrm{ml} / \mathrm{min}$ with PDA detection from $280 \mathrm{~nm}$. The volume of the injection was $10 \mu \mathrm{l}$.
Preparations of sample and standard solutions. Standard stock solutions of four flavonoids [(+)-catechin, (-)-epicatechin, eriodictyol and quercetin)] and two phenolic compounds (caffeic acid and ethyl gallate) were dissolved in methanol at a concentration of $1.0 \mu \mathrm{g} / \mathrm{ml}$ and maintained at $<4^{\circ} \mathrm{C}$. Working standard solutions were prepared by serial dilution of stock solutions with methanol. The extracts $(40 \mathrm{mg}$ ) of each lyophilized fraction, such as $70 \%$ ethanol, $n$-hexane, ethyl acetate, $n$-butanol and water fractions, were each dissolved in $70 \%$ ethanol (20 ml, respectively). The solutions were filtered through a $0.2-\mu \mathrm{m}$ syringe filter (Woong Ki Science Co., Ltd, Seoul, Republic of Korea).

Calibration curves and limits of quantification (LOQ) and detection ( $L O D)$. All calibration curves were obtained by the assessment of peak areas from standard solutions in the seven different concentration ranges, from 0.78 to $50.00 \mu \mathrm{g} / \mathrm{ml}$. The LOD and LOQ data were determined based on signal-to-noise ratios of 3 and 10 , respectively.

Cell culture. The HaCaT human keratinocyte and RAW 264.7 murine macrophage cell lines were obtained from the American Type Culture Collection (Rockville, MD, USA). These cells were cultured in Dulbecco's Modified Eagle's Medium (Gibco-BRL, Grand Island, NY, USA) supplemented with $10 \%$ (HaCaT) or 5.5\% (RAW 264.7) heat-inactivated fetal bovine serum (Gibco-BRL), streptomycin $(100 \mu \mathrm{g} / \mathrm{ml})$ and penicillin $(100 \mathrm{U} / \mathrm{ml})$ at $37^{\circ} \mathrm{C}$ in a $5 \% \mathrm{CO}_{2}$ incubator.

Cytotoxicity assay. Cell viability was assessed using the Cell Counting Kit-8 (CCK-8) reagent (Dojindo Laboratories, Kumamoto, Japan), according to the manufacturer's instructions. RAW $264.7\left(3 \times 10^{3}\right.$ cells/well $)$ and HaCaT $\left(1 \times 10^{3}\right.$ cells/well $)$ cells were incubated in 96-well plates with various concentrations of the test materials for $24 \mathrm{~h}$. Following the addition of CCK-8 reagent to each well the cells were further incubated for 4 h. A Benchmark Plus microplate reader (Bio-Rad, Hercules, CA, USA) was used to measure absorbance at $450 \mathrm{~nm}$, and the cell viability percentage was calculated using the following formula: Cell viability $(\%)=[($ mean absorbance in test wells - mean absorbance in blank wells)/(mean absorbance in control wells - mean absorbance in blank wells)] x 100.

Measurement of $\mathrm{PGE}_{2}$ and $\mathrm{NO}$ production. RAW 264.7 cells were plated in 48 -well plates at a density of $2.5 \times 10^{5}$ cells/well and incubated overnight. The cells were then treated with LPS (1 $\mu \mathrm{g} / \mathrm{ml}$; Sigma-Aldrich, St. Louis, MO, USA) in the presence or absence of various concentrations of the test materials. Following incubation for $24 \mathrm{~h}$, ELISA kits were used to analyze the supernatants for the levels of $\mathrm{PGE}_{2}$ (Cayman Chemical Co., Ann Arbor, MI, USA) and NO (Griess Reagent System; Promega Biotech Co., Ltd., Madison, WI, USA), according to the manufacturers' instructions. N(G)-Monomethyl-L-arginine (L-NMMA; Sigma-Aldrich) and indomethacin (Sigma-Aldrich) were used as positive controls to inhibit the production of $\mathrm{NO}$ and $\mathrm{PGE}_{2}$, respectively.

Measurement of chemokine production. HaCaT cells $\left(1 \times 10^{6}\right.$ cells/well) were cultured in six-well plates in medium 
Table I. Linearities, correlation coefficients, LODs and LOQs of the six constituents $(n=3)$.

\begin{tabular}{|c|c|c|c|c|c|}
\hline Compound & Linear range $(\mu \mathrm{g} / \mathrm{ml})$ & Regression equation $^{\mathrm{a}}$ & Correlation coefficient $\left(r^{2}\right)$ & $\operatorname{LOD}^{\mathrm{b}}(\mu \mathrm{g} / \mathrm{ml})$ & $\mathrm{LOQ}^{\mathrm{c}}(\mu \mathrm{g} / \mathrm{ml})$ \\
\hline$(+)$-Catechin & $0.78-50.00$ & $y=2,779.71 x+274.75$ & 0.9999 & 0.425 & 1.418 \\
\hline Caffeic acid & $0.78-50.00$ & $y=34,405.46 x-9,908.57$ & 0.9998 & 0.039 & 0.132 \\
\hline (-)-Epicatechin & $0.78-50.00$ & $\mathrm{y}=7,859.71 x+1,909.87$ & 0.9999 & 0.130 & 0.433 \\
\hline Ethyl gallate & $0.78-50.00$ & $y=24,543.65 x+2,271.17$ & 0.9999 & 0.051 & 0.171 \\
\hline Eriodictyol & $0.78-50.00$ & $y=34,836 x+6,410.25$ & 0.9999 & 0.037 & 0.124 \\
\hline Quercetin & $0.78-50.00$ & $y=13,439.20 x-676.53$ & 0.9998 & 0.118 & 0.395 \\
\hline
\end{tabular}

${ }^{\mathrm{a}} y$, peak area (mAU) of constituents; $x$, concentration $(\mu \mathrm{g} / \mathrm{ml})$ of constituents. ${ }^{b} \mathrm{LOD}=3 \mathrm{x}$ signal-to-noise ratio. ${ }^{\mathrm{c}} \mathrm{LOQ}=10 \mathrm{x}$ signal-to-noise ratio. $\mathrm{LOD}$, limit of detection; $\mathrm{LOQ}$, limit of quantification.

containing $10 \%$ fetal bovine serum. After reaching confluence, the cells were washed and treated with the test materials in $1 \mathrm{ml}$ serum-free medium containing TI (10 ng/ml TNF- $\alpha$ and $10 \mathrm{ng} / \mathrm{ml}$ IFN- $\gamma$; R\&D Systems Inc., Minneapolis, MN, USA) for $24 \mathrm{~h}$. The supernatants of the cells were harvested, and the production of TARC, MDC and RANTES was quantified using ELISA (R\&D Systems, Inc.), which was performed according to the manufacturer's instructions.

Statistical analysis. All experiments of the present study were performed at least in triplicate. Significant differences between the treatment groups were identified using one-way analysis of variance and multigroup comparisons were performed using the Dunnett's test. $\mathrm{P}<0.05$ was considered to indicate a statistically significant difference.

\section{Results}

Calibration curves, $L O D$ and $L O Q$. The linearity of the peak area $(\mathrm{y})$ versus concentration $(\mathrm{x}, \mu \mathrm{g} / \mathrm{ml})$ curve for each component was used to calculate the contents of the six constituents in each fraction of the $G$. sinensis extract. The correlation coefficients $\left(r^{2}\right)$ of the calibration curves of the six constituents were $\geq 0.9998$. The line equations and $r^{2}$ of the calibration curves are shown in Table I. The ranges of LOD and LOQ were 0.037-0.425 and 0.124-1.418 $\mu \mathrm{g} / \mathrm{ml}$, respectively (Table I).

HPLC analysis. Good separation chromatograms were obtained using mobile phases consisting of $1.0 \%(\mathrm{v} / \mathrm{v})$ aqueous acetic acid (solvent $\mathrm{A}$ ) and acetonitrile with $1.0 \%$ (v/v) acetic acid (solvent B). Quantification was achieved using PDA detection at $280 \mathrm{~nm}$, based on retention times and ultraviolet spectra. Fig. 1 shows the representative HPLC chromatogram of the standards and each fraction of the $G$. sinensis extract, with detection of eluents at $280 \mathrm{~nm}$. Reproducibility was assessed by measuring repeatedly the retention times and peak areas of six independently prepared samples of analytes. The reproducibility of the six compounds $[(+)$-catechin, caffeic acid, (-)-epicatechin, eriodictyol, ethyl gallate and quercetin] was less than the relative standard deviation (RSD) $1.5 \%$ for peak responses and less than the RSD $0.2 \%$ for retention times (data not shown). The contents of the six constituents are summarized in Table II.
$G$. sinensis extract inhibits $N O$ and $P G E_{2}$ production in RAW 264.7 cells and TARC production in HaCaT cells. The cytotoxic effect of the G. sinensis extract on RAW 264.7 and $\mathrm{HaCaT}$ cells was measured first. The cells were exposed to various concentrations $(2-200 \mu \mathrm{g} / \mathrm{ml})$ of the $G$. sinensis extract for $24 \mathrm{~h}$. The non-toxic concentrations of the test materials were used in subsequent experiments (data not shown). To determine the effects of the $G$. sinensis extract on $\mathrm{NO}$ and $\mathrm{PGE}_{2}$ production in LPS-stimulated RAW 264.7 cells, the cells were treated with different concentrations of the $G$. sinensis extract $(25,50$ and $100 \mu \mathrm{g} / \mathrm{ml})$ and then stimulated by LPS $(1 \mu \mathrm{g} / \mathrm{ml})$ for $24 \mathrm{~h}$. The $G$. sinensis extract suppressed LPS-stimulated NO production in a dose-dependent manner (Fig. 2A). LPS greatly stimulated NO production $(5.846 \pm 0.220 \mathrm{nM})$ in RAW 264.7 cells, whereas the $G$. sinensis extract significantly decreased NO production $[1.872 \pm 0.513 \mu \mathrm{M}(\mathrm{P}<0.01)$ at a dose of $25 \mu \mathrm{g} / \mathrm{ml}, 0.974 \pm 0.128 \mu \mathrm{M}(\mathrm{P}<0.01)$ at a dose of $50 \mu \mathrm{g} / \mathrm{ml}$ and $0.205 \pm 0.020 \mu \mathrm{M}(\mathrm{P}<0.01)$ at a dose of $100 \mu \mathrm{g} / \mathrm{ml}]$ compared with that observed in LPS-stimulated RAW 264.7 cells. Furthermore, LPS-stimulated RAW 264.7 cells exhibited increased $\mathrm{PGE}_{2}$ production compared with the controls, whereas the $G$. sinensis extract decreased the production of $\mathrm{PGE}_{2}$ relative to the production observed in the LPS-stimulated RAW 264.7 cells (Fig. 2B). The effects of the G. sinensis extract on TARC production in TI-stimulated HaCaT cells were assessed by treating the cells with different concentrations of the $G$. sinensis extract (50, 100 and $200 \mu \mathrm{g} / \mathrm{ml})$ and then initiating TI stimulation for $24 \mathrm{~h}$. The $G$. sinensis extract suppressed TI-stimulated TARC production in a dose-dependent manner (Fig. 2C). TI-treated cells showed significantly increased production of TARC $(28.27 \pm 0.900 \mathrm{ng} / \mathrm{ml})$ relative to that observed in the control cells $(\mathrm{P}<0.01)$. This increase was inhibited to $22.44 \pm 0.030 \mathrm{ng} / \mathrm{ml}(\mathrm{P}<0.01)$ and $10.23 \pm 0.480 \mathrm{ng} / \mathrm{ml}$ $(\mathrm{P}<0.01)$ by the administration of the $G$. sinensis extract at 100 and $200 \mu \mathrm{g} / \mathrm{ml}$, respectively.

Fractions of the $G$. sinensis extract inhibit $N O$ and $P G E_{2}$ production in RAW 264.7 cells and TARC production in $\mathrm{HaCaT}$ cells. Fractions of the G. sinensis extract were tested to determine whether each fraction inhibited the production of $\mathrm{NO}$ and $\mathrm{PGE}_{2}$ in LPS-treated RAW 264.7 cells and the production of TARC in HaCaT cells treated with TI. NO production is the hallmark of the activation of macrophages. In the present experiment, NO production $(4.308 \pm 0.225 \mu \mathrm{M})$ was 
A<smiles>Oc1cc(O)c2c(c1)OC(c1ccc(O)c(O)c1)C(O)C2</smiles><smiles>O=C(O)/C=C/c1ccc(O)c(O)c1</smiles>

Caffeic acid<smiles>Oc1cc(O)c2c(c1)OC(c1ccc(O)c(O)c1)C(O)C2</smiles>

$(+)$-Catechin $\mathrm{OH}$<smiles>O=C1CC(c2ccc(O)c(O)c2)Oc2cc(O)cc(O)c21</smiles>

Eriodictyol
(-)-Epicatechin<smiles></smiles>

Quercetin

Ethyl gallate

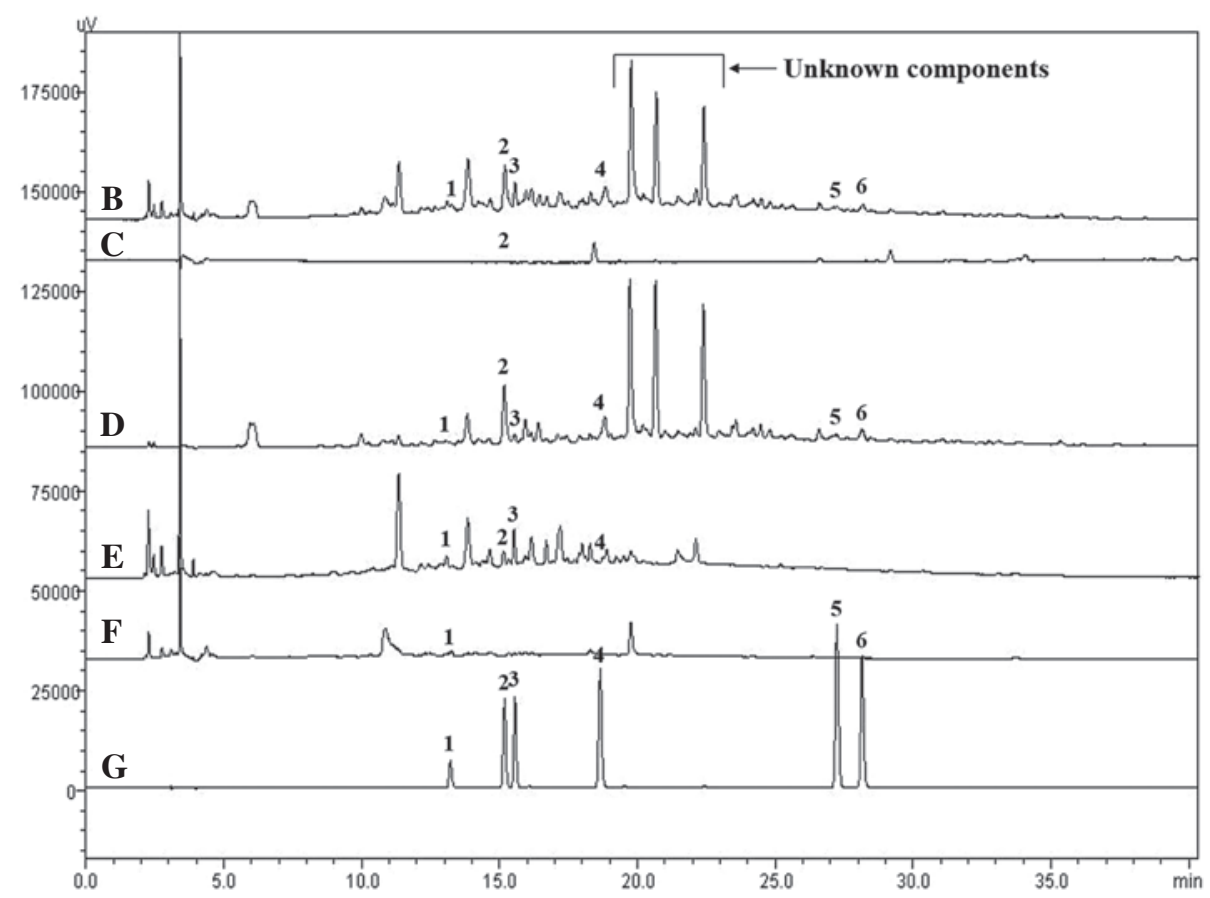

Figure 1. Chemical structures of the six constituents and high-performance liquid chromatography chromatogram of Gleditsia sinensis. (A) Chemical structures of the six constituents. (B-G) Chromatogram of (B) $70 \%$ ethanol extract, (C) $n$-hexane, (D) ethyl acetate, (E) $n$-butanol, (F) water fractions and (G) standard mixture. Peaks are labeled as follows: 1, (+)-Catechin; 2, caffeic acid; 3, (-)-epicatechin; 4, ethyl gallate; 5, eriodictyol; and 6, quercetin.

observed after $24 \mathrm{~h}$ of LPS incubation $(1 \mu \mathrm{g} / \mathrm{ml})$. As shown in Fig. 3A, treatment with the $n$-hexane, ethyl acetate and $n$-butanol fractions suppressed the NO production. In addition, the $n$-hexane and ethyl acetate fractions decreased $\mathrm{PGE}_{2}$ production compared with that observed in LPS-stimulated RAW 264.7 cells $(\mathrm{P}<0.01$, Fig. 3B). TARC production was increased 2.7 -fold in the TI-treated cells $(28.30 \pm 0.820 \mathrm{ng} / \mathrm{ml})$ compared with that in the control cells $(10.16 \pm 1.540 \mathrm{ng} / \mathrm{ml})$ $(\mathrm{P}<0.01)$, whereas cells treated with the ethyl acetate fraction showed the most significant reductions in TARC production compared with the TI-treated cells $(\mathrm{P}<0.01$, Fig. $3 \mathrm{C})$. These results showed that the biological effects of $G$. sinensis were maximized by the ethyl acetate fraction.

Major constituents of the G. sinensis extract inhibit NO and $P G E_{2}$ production in RAW 264.7 cells and chemokine production in $\mathrm{HaCaT}$ cells. To assess the effects of the major constituents of the G. sinensis extract on LPS-stimulated $\mathrm{NO}$ and $\mathrm{PGE}_{2}$ production in RAW 264.7 macrophages, cells were treated with various concentrations of these major constituents and $1 \mu \mathrm{g} / \mathrm{ml}$ LPS for $24 \mathrm{~h}$. LPS stimulation caused a marked accumulation of proinflammatory mediators ( $\mathrm{NO}$ and $\mathrm{PGE}_{2}$ ) in the culture medium. Of note, all major constituents of the $G$. sinensis extract significantly reduced the LPS-stimulated production of $\mathrm{NO}$ (Fig. 4A) and $\mathrm{PGE}_{2}$ (Fig. 4B) in a dose-dependent manner. Treatment of $\mathrm{HaCaT}$ cells with TI for $24 \mathrm{~h}$ led to a 1.9-fold increase in TARC levels $(6.85 \pm 0.51 \mathrm{ng} / \mathrm{ml})$ compared with that observed in the vehicle-treated control group $(3.52 \pm 0.29 \mathrm{ng} / \mathrm{ml})(\mathrm{P}<0.01)$; however, TARC production was significantly inhibited in a dose-dependent manner in the ethyl gallate-, eriodictyol- and quercetin-treated cells $(\mathrm{P}<0.01)$ (Fig. 4C). In addition, MDC production was increased in the TI-treated cells $(264.80 \pm 12.76 \mathrm{ng} / \mathrm{ml})$ compared with that in the vehicle-treated control group $(\mathrm{P}<0.01)$, and its levels were significantly reduced following ethyl gallate and quercetin treatment $(\mathrm{P}<0.01)$ (Fig. 4D). TI-treated cells exhibited a significantly increased production of RANTES 


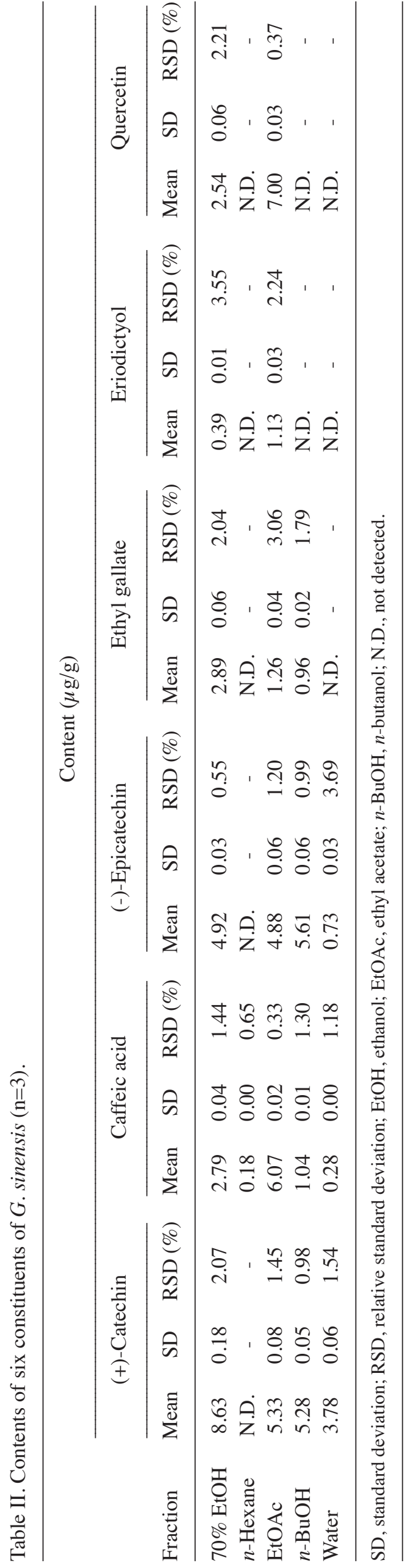

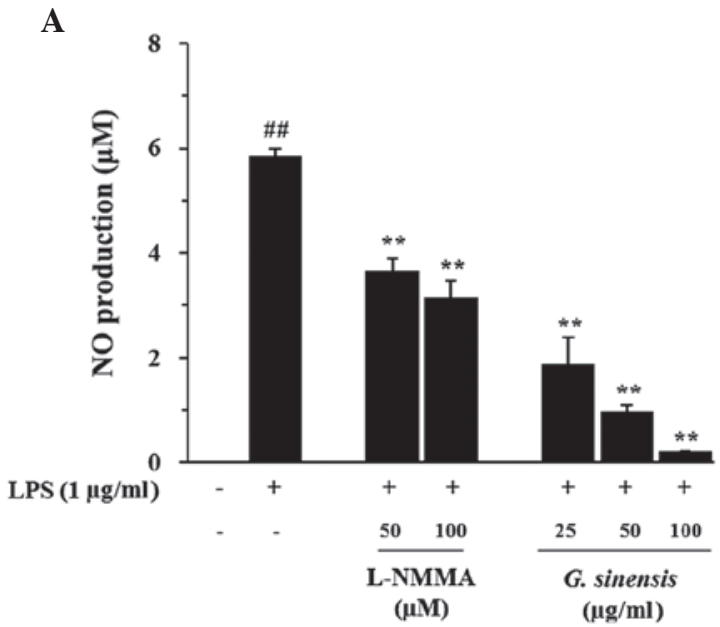

B

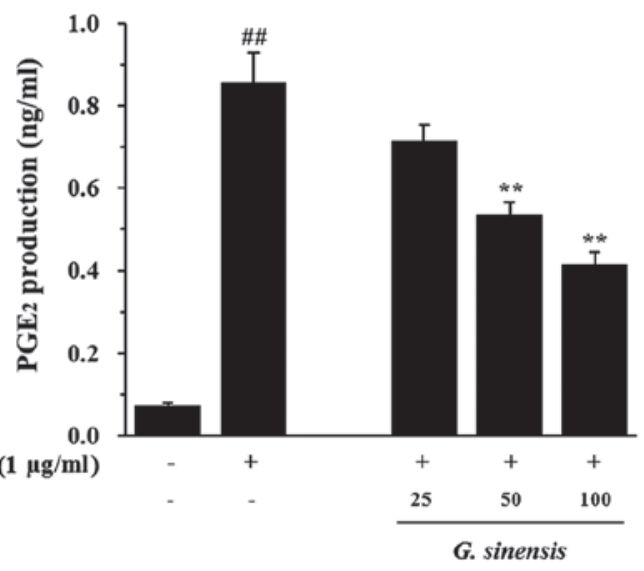

C

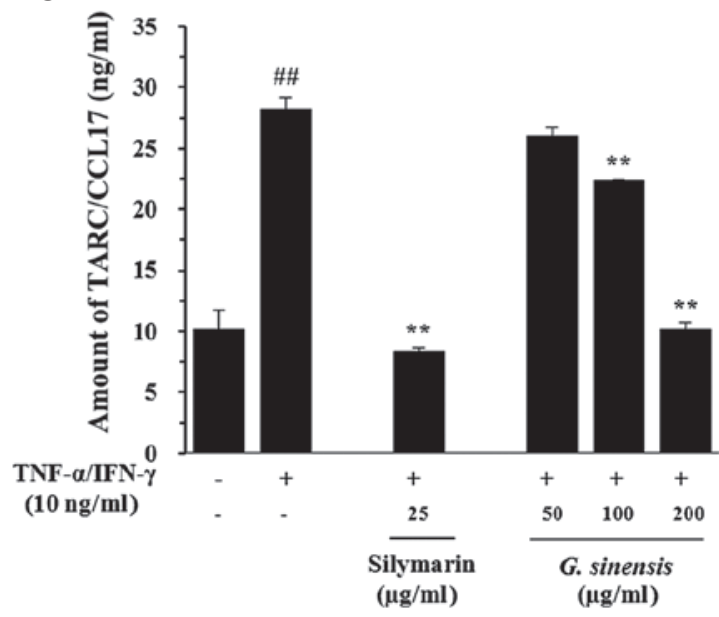

Figure 2. Effects of the extract of Gleditsia sinensis on the LPS-stimulated production of $\mathrm{NO}$ and $\mathrm{PGE}_{2}$ in RAW 264.7 cells and the TI-stimulated production of TARC in HaCaT cells. The production of (A) NO and (B) $\mathrm{PGE}_{2}$ was assayed in the culture medium of cells treated with extracts of $G$. sinensis $(25,50$, and $100 \mu \mathrm{g} / \mathrm{ml})$ and then with LPS $(1 \mu \mathrm{g} / \mathrm{ml})$ for $24 \mathrm{~h}$. L-NMMA $(25 \mu \mathrm{M})$ was used as a positive control drug. (C) The production of TARC was assayed in the culture medium of cells treated with extracts of G. sinensis (50,100 and $200 \mu \mathrm{g} / \mathrm{ml}$ ), followed by TI (TNF- $\alpha$, $10 \mathrm{ng} / \mathrm{ml}$; IFN- $\gamma, 10 \mathrm{ng} / \mathrm{ml})$ for $24 \mathrm{~h}$. Silymarin $(25 \mu \mathrm{g} / \mathrm{ml})$ was used as a positive control drug. Each bar represents the mean values obtained from three independent experiments. ${ }^{\# \#} \mathrm{P}<0.01$ vs. the vehicle control group; ${ }^{* *} \mathrm{P}<0.01$ vs. LPS/TI-treated cells. LPS, lipopolysaccharide; NO, nitric oxide; $\mathrm{PGE}_{2}$, prostaglandin $\mathrm{E}_{2}$, TARC, thymus- and activation-regulated chemokine; TNF- $\alpha$, tumor necrosis factor- $\alpha$; IFN- $\gamma$, interferon- $\gamma$; TI, TNF- $\alpha$ and IFN- $\gamma$; L-NMMA, N(G)-monomethyl-L-arginine. 

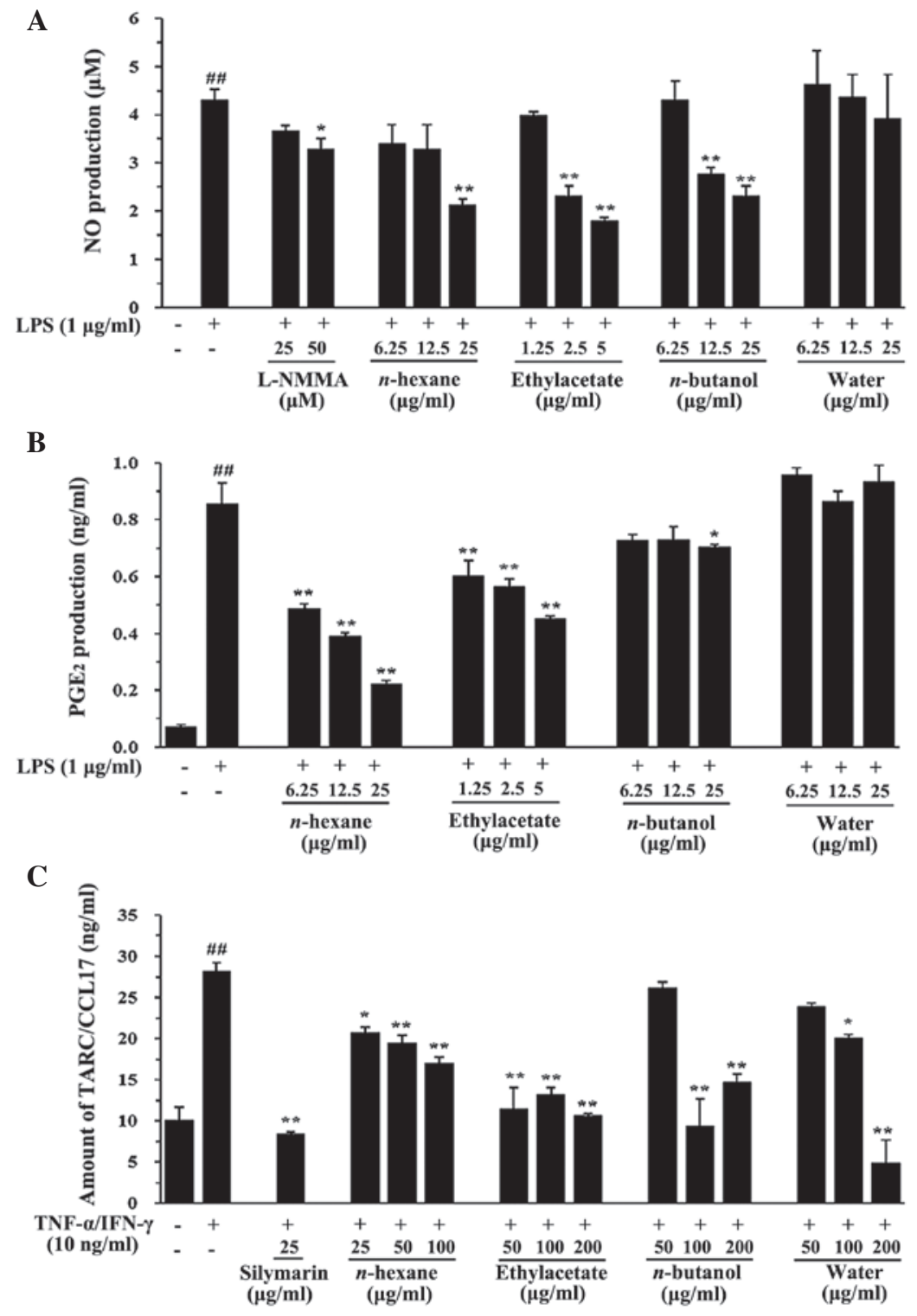

Figure 3. Effects of the fractions of Gleditsia sinensis extract on the LPS-stimulated production of NO and $\mathrm{PGE}_{2}$ in RAW 264.7 cells and the TI-stimulated production of TARC in $\mathrm{HaCaT}$ cells. The production of (A) $\mathrm{NO}$ and (B) $\mathrm{PGE}_{2}$ was assayed in the culture medium of cells treated with solvent fractions and then stimulated with LPS $(1 \mu \mathrm{g} / \mathrm{ml})$ for $24 \mathrm{~h}$. L-NMMA $(25 \mu \mathrm{M})$ was used as a positive control drug. (C) The production of TARC was assayed in the culture medium of cells treated with solvent fractions and then stimulated with TI (TNF- $\alpha, 10 \mathrm{ng} / \mathrm{ml}$; IFN- $\gamma, 10 \mathrm{ng} / \mathrm{ml}$ ) for $24 \mathrm{~h}$. Silymarin $(25 \mu \mathrm{g} / \mathrm{ml})$ was used as a positive control drug. Each bar represents the mean values obtained from three independent experiments. ${ }^{\# \#} \mathrm{P}<0.01$ vs. the vehicle control group; ${ }^{*} \mathrm{P}<0.05$ and ${ }^{* *} \mathrm{P}<0.01$ vs. the LPS/TI-treated cells. LPS, lipopolysaccharide; $\mathrm{NO}$, nitric oxide; $\mathrm{PGE}_{2}$, prostaglandin $\mathrm{E}_{2}$, TARC, thymus- and activation-regulated chemokine; TNF- $\alpha$, tumor necrosis factor- $\alpha$; IFN- $\gamma$, interferon- $\gamma$; TI, TNF- $\alpha$ and IFN- $\gamma$; L-NMMA, N(G)-monomethyl-L-arginine.

$(4,652.93 \pm 66.95 \mathrm{ng} / \mathrm{ml})$, relative to that observed in the control cells $(\mathrm{P}<0.01)$. This increase was inhibited dose-dependently by ethyl gallate $(2,530.11 \pm 8.67 \mathrm{ng} / \mathrm{ml}$ at $50 \mu \mathrm{g} / \mathrm{ml}, \mathrm{P}<0.01 ; 1,068.30 \pm 95.01 \mathrm{ng} / \mathrm{ml}$ at $100 \mu \mathrm{g} / \mathrm{ml}$, $\mathrm{P}<0.01)$, eriodictyol $(3,987.98 \pm 127.92 \mathrm{ng} / \mathrm{ml}$ at $50 \mu \mathrm{g} / \mathrm{ml}$, $\mathrm{P}<0.05 ; 2,433.12 \pm 184.17 \mathrm{ng} / \mathrm{ml}$ at $100 \mu \mathrm{g} / \mathrm{ml}, \mathrm{P}<0.01)$ and quercetin $(2,728.46 \pm 119.93 \mathrm{ng} / \mathrm{ml}$ at $50 \mu \mathrm{g} / \mathrm{ml}, \mathrm{P}<0.01$; $414.34 \pm 27.59 \mathrm{ng} / \mathrm{ml}$ at $100 \mu \mathrm{g} / \mathrm{ml}, \mathrm{P}<0.01$ ) (Fig. 4E). Among these compounds, ethyl gallate and quercetin, which were most abundant both in the G. sinensis extract and in each solvent fraction (particularly in the ethyl acetate fraction) significantly inhibited the RANTES, MDC and TARC expression in $\mathrm{HaCaT}$ cells in a dose-dependent manner, whereas the same expression was not significantly reduced by other constituents in TI-treated cells.

\section{Discussion}

The seeds and fruits of G. sinensis are widely used in Chinese, Japanese and Korean herbal medicine for the treatment of numerous diseases, such as apoplexy, headache, asthma and scabies (14). Despite the fact that the thorns of G. sinensis have been used for the prevention, as well as the treatment, of carbuncles, scabies and other inflammatory diseases (15), the anti-inflammatory effect has not yet been fully elucidated. In the present study, the concentrations of the chemical constituents of $G$. sinensis and their anti-inflammatory effects in G. sinensis extracts, based on different solvent fractions and single compounds, were investigated.

Two phenolic compounds (caffeic acid and ethyl gallate) and four flavonoids $[(+)$-catechin, (-)-epicatechin, eriodictyol 
A

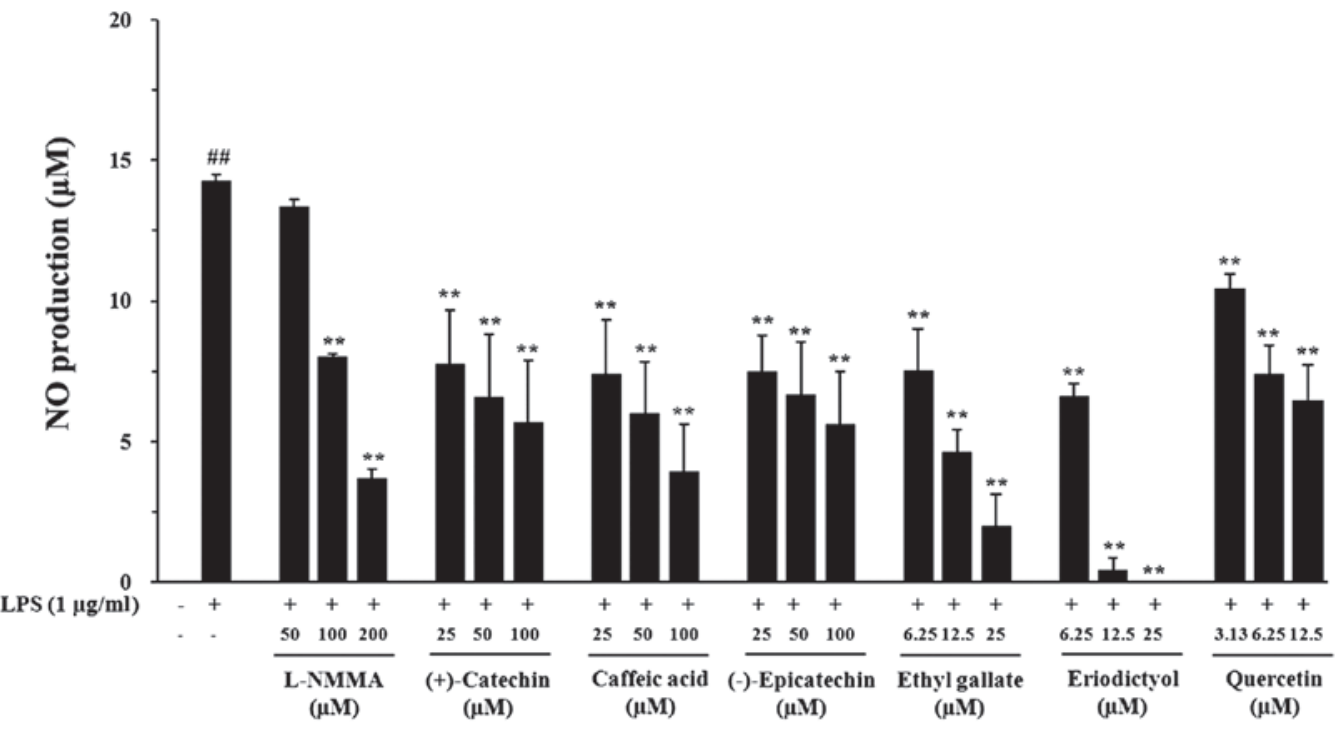

B

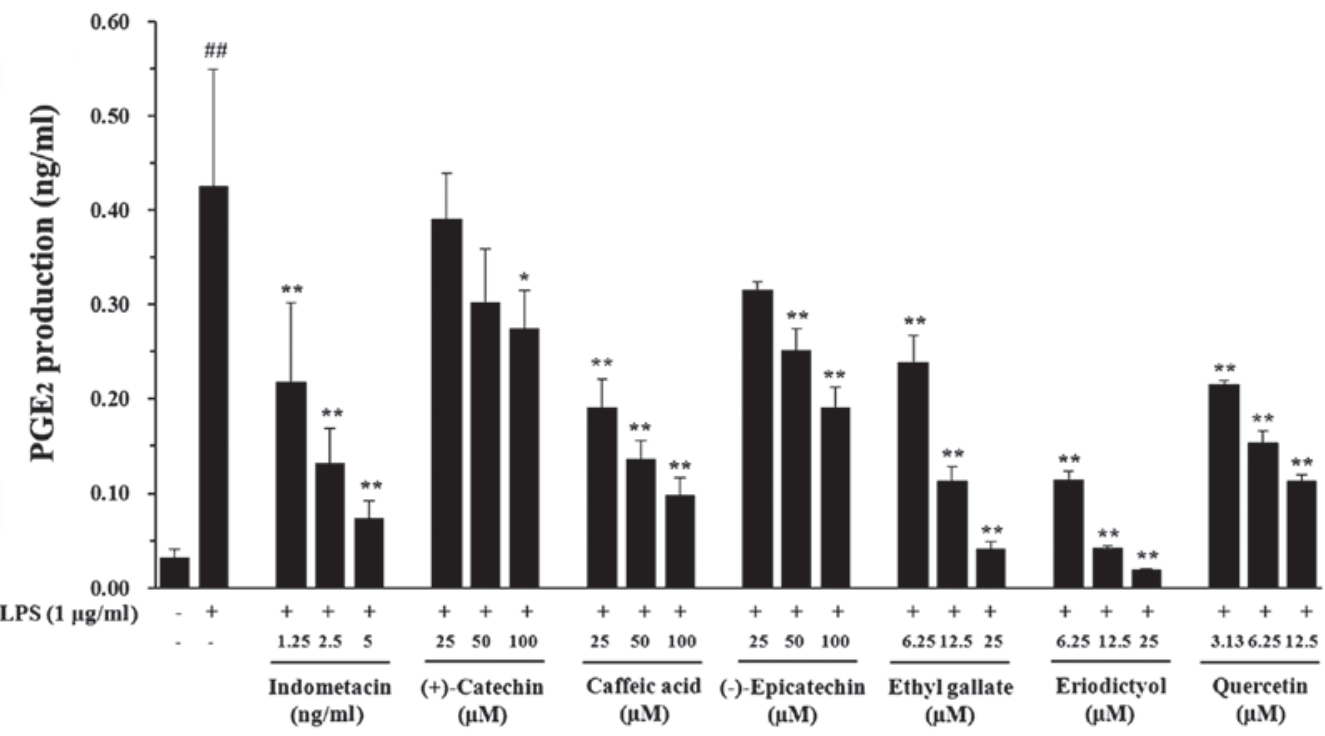

$\mathbf{C}$

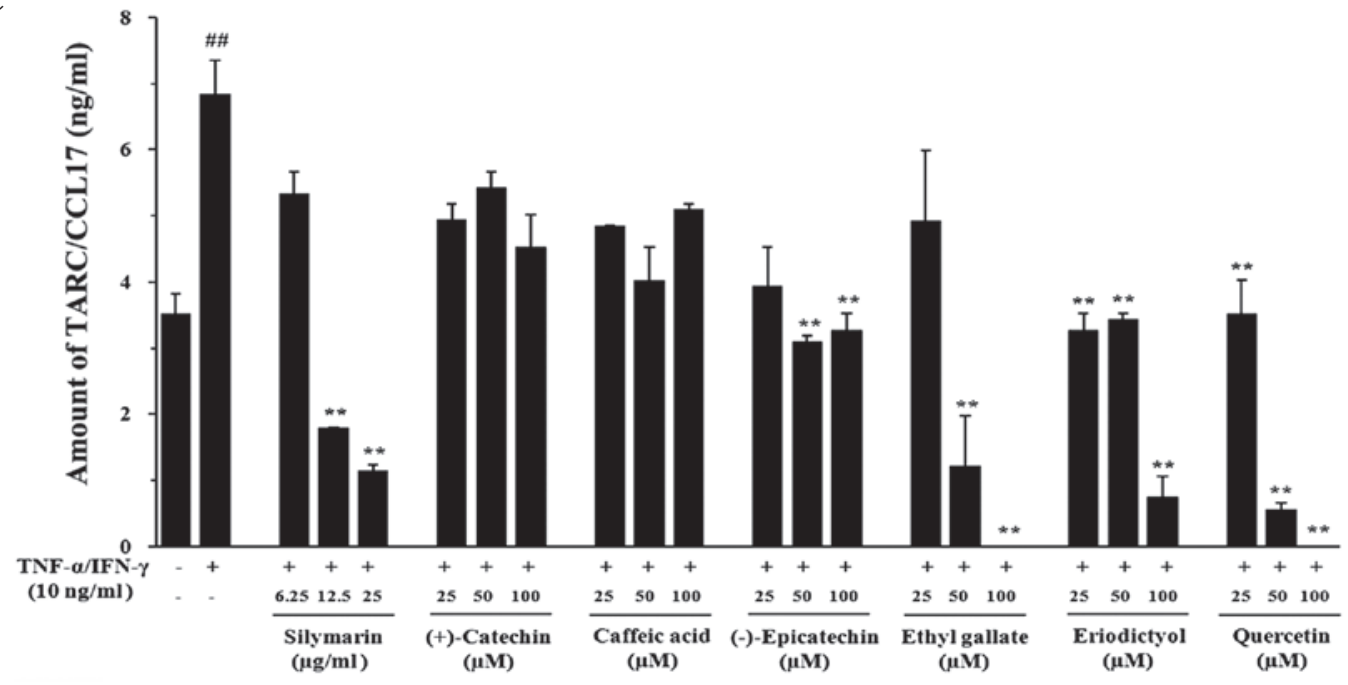

Figure 4. Effects of the major constituents of the Gleditsia sinensis extract on the LPS-stimulated production of NO and PGE 2 in RAW 264.7 cells and the TI-stimulated production of chemokines in $\mathrm{HaCaT}$ cells. The production of (A) $\mathrm{NO}$ and (B) $\mathrm{PGE}_{2}$ was assayed in the culture medium of cells treated with the major constituents of the G. sinensis extract and then stimulated with LPS $(1 \mu \mathrm{g} / \mathrm{ml})$ for $24 \mathrm{~h}$. L-NMMA $(25 \mu \mathrm{M})$ was used as a positive control drug. (C) The production of TARC was assayed in the culture medium of cells treated with the major constituents of the G. sinensis extract and then stimulated with TI (TNF- $\alpha, 10 \mathrm{ng} / \mathrm{ml}$; IFN- $\gamma, 10 \mathrm{ng} / \mathrm{ml}$ ) for $24 \mathrm{~h}$. Silymarin $(25 \mu \mathrm{g} / \mathrm{ml})$ was used as positive control drug. Each bar represents the mean of three independent experiments. ${ }^{\# \#} \mathrm{P}<0.01$ vs. the vehicle control group; ${ }^{*} \mathrm{P}<0.05$ and ${ }^{* *} \mathrm{P}<0.01$ vs. the LPS/TI-treated cells. LPS, lipopolysaccharide; NO, nitric oxide; PGE ${ }_{2}$, prostaglandin $\mathrm{E}_{2}$, TARC, thymus- and activation-regulated chemokine; TNF- $\alpha$, tumor necrosis factor- $\alpha$; IFN- $\gamma$, interferon- $\gamma$; TI, TNF- $\alpha$ and IFN- $\gamma$; L-NMMA, N(G)-monomethyl-L-arginine. 

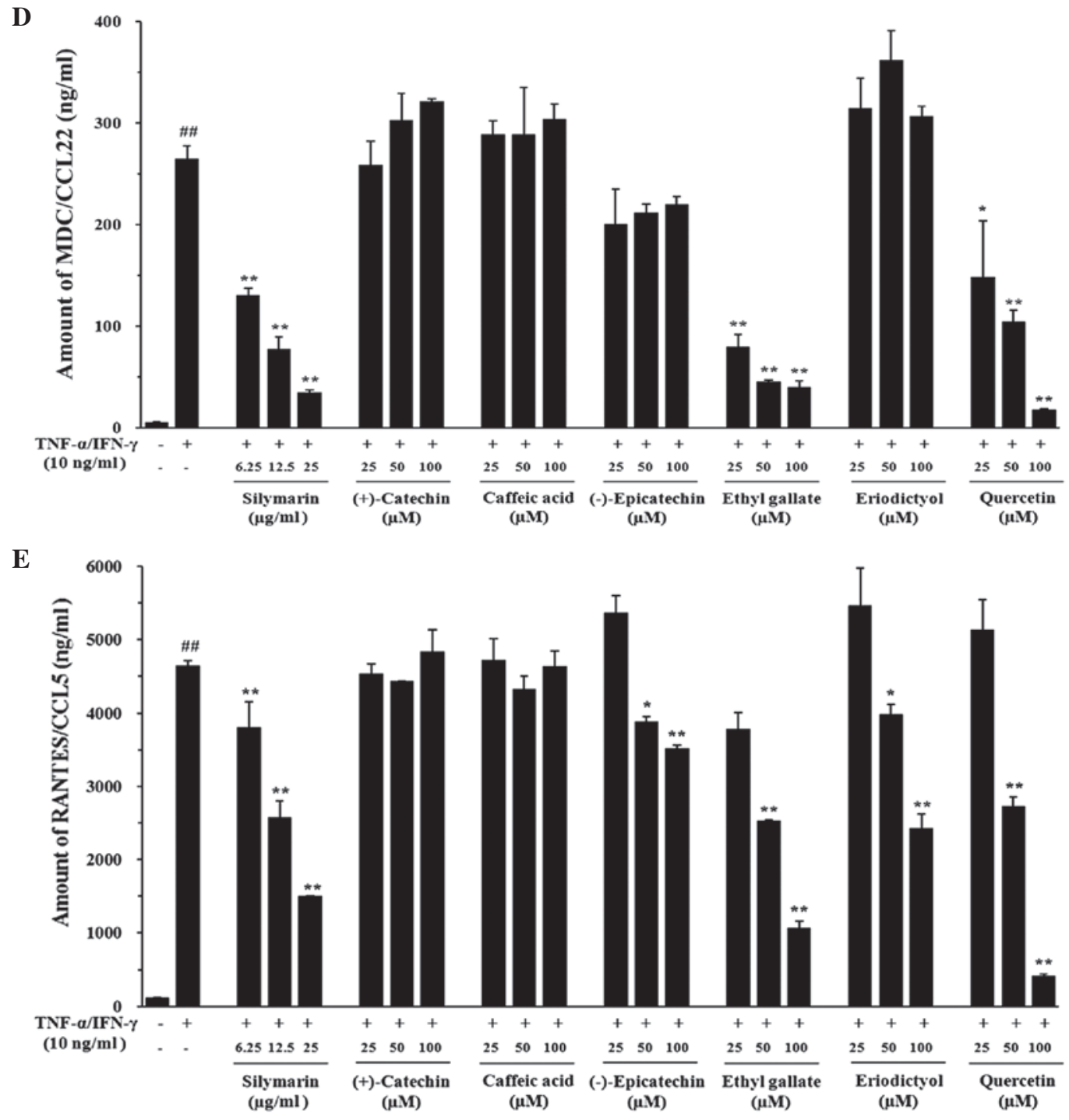

Figure 4. Continued. Effects of the major constituents of the Gleditsia sinensis extract on LPS-stimulated production of $\mathrm{NO}_{\text {and }} \mathrm{PGE}_{2}$ in RAW 264.7 cells and the TI-stimulated production of chemokines in HaCaT cells. The production of (D) MDC and (E) RANTES was assayed in the culture medium of cells treated with the major constituents of the $G$. sinensis extract and then stimulated with TI (TNF- $\alpha, 10 \mathrm{ng} / \mathrm{ml} ; \mathrm{IFN}-\gamma, 10 \mathrm{ng} / \mathrm{ml}$ ) for $24 \mathrm{~h}$. Silymarin $(25 \mu \mathrm{g} / \mathrm{ml})$ was used as positive control drug. Each bar represents the mean of three independent experiments. ${ }^{\# \#} \mathrm{P}<0.01$ vs. the vehicle control group; ${ }^{*} \mathrm{P}<0.05$ and ${ }^{* *} \mathrm{P}<0.01$ vs. the LPS and TI-treated cells, respectively. LPS, lipopolysaccharide; $\mathrm{NO}$, nitric oxide; $\mathrm{PGE}_{2}$, prostaglandin $\mathrm{E}_{2}, \mathrm{TARC}$, thymus- and activation-regulated chemokine; TNF- $\alpha$, tumor necrosis factor- $\alpha$; IFN- $\gamma$, interferon- $\gamma ;$ MDC, macrophage-derived chemokine; RANTES, regulated on activation normal T-cell expressed and secreted; TI, TNF- $\alpha$ and IFN- $\gamma$.

and quercetin)] were analyzed in $70 \%$ ethanol extracts and solvent fractions ( $n$-hexane, ethyl acetate, $n$-butanol and water) of $G$. sinensis; however, the constituents responsible for peaks at the retention times of 19.8, 20.7 and $22.5 \mathrm{~min}$ in the $70 \%$ ethanol extract and ethyl acetate fraction were not able to be identified. It is imperative that these constituents are identified and quantitatively determined in order for a correlation between the quantities of the major constituents of $G$. sinensis and the biological effects of this herbal medicine to be obtained.

The production of $\mathrm{NO}$ and $\mathrm{PGE}_{2}$, two major mediators of inflammation, plays an important role in the immune response to numerous inflammatory stimuli. The free radical NO is produced by iNOS, and its overproduction has been associated with the pathology of an array of inflammatory disorders, such as septic shock (16). $\mathrm{PGE}_{2}$, which is generated from arachidonic acid by $\mathrm{COX}-2$, is produced in response to inflammatory stimuli, and abundant COX-2 expression promotes the proinflammatory signaling cascade (17). Thus, potential inhibitors of iNOS and COX-2 have been considered as possible anti-inflammatory agents. It was shown that the extraction solvent and the major constituents in G. sinensis reduced the levels of $\mathrm{NO}$ and $\mathrm{PGE}_{2}$ in LPS-stimulated RAW 264.7 cells in a dose-dependent manner.

Exposure of keratinocytes to TI results in an abnormal expression of chemokines and cytokines, which is believed to increase the infiltration of monocytes/T cells into the site of inflammation $(18,19)$. Chemokines are a superfamily of small cytokines that regulate the trafficking of various types of leukocytes (20). TARC/CCL17 is a member of the CC chemokine subfamily that is produced by various cell types, including keratinocytes, and is constitutively expressed in the thymus (21). MDC/CCL22 is closely associated with TARC and is constitutively produced by dendritic cells, B 
cells, keratinocytes, epithelial cells and macrophages (22). RANTES/CCL5 belongs to the CC chemokine family, the members of which recruit and activate different subtypes of leukocytes, such as T cells, eosinophils, basophils, monocytes or mast cells (23). The effect of the extract and solvent fractions of $G$. sinensis on TARC production in TI-stimulated HaCaT cells was examined and it was shown that the major constituents of $G$. sinensis reduced the production of TARC, MDC and RANTES in TI-stimulated HaCaT cells; in particular, ethyl gallate and quercetin yielded a significant dose-dependent inhibition.

In conclusion, the $G$. sinensis extract was successively partitioned to identify the fraction that contained the major constituent compounds. It was found that all the reference compounds were present in the ethyl acetate fraction and that larger amounts were present in this fraction than in any other fraction. Furthermore, the ethyl acetate fraction decreased the levels of $\mathrm{NO}$ and $\mathrm{PGE}_{2}$ in RAW 264.7 cells and the expression of TARC, MDC and RANTES in HaCaT cells to a greater extent than the other fractions. Further elucidation of the signaling pathways involved in T-helper cell 2 chemokine inhibition by $G$. sinensis is required for the facilitation of the design of therapeutic agents for the inflammatory reaction.

\section{Acknowledgements}

This study was supported by grants from the Korea Research Council of Fundamental Science \& Technology (grant no. G10101) and the Korea Institute of Oriental Medicine (grant no. K13030).

\section{References}

1. Damte D, Reza MA, Lee SJ, Jo WS and Park SC: Anti-inflammatory activity of dichloromethane extract of Auricularia auricula-judae in RAW264.7 cells. Toxicol Res 27: 11-14, 2011

2. Duffield JS: The inflammatory macrophage: A story of Jekyll and Hyde. Clin Sci (Lond) 104: 27-38, 2003.

3. Gordon S: Alternative activation of macrophages. Nat Rev Immunol 3: 23-35, 2003.

4. Mosser DM and Edwards JP: Exploring the full spectrum of macrophage activation. Nat Rev Immunol 8: 958-969, 2008.

5. Rossi D and Zlotnik A: The biology of chemokines and their receptors. Annu Rev Immunol 18: 217-242, 2000.

6. Vestergaard C, Yoneyama H, Murai M, Nakamura K, Tamaki K, Terashima Y, Imai T, Yoshie O, Irimura T, Mizutani $\mathrm{H}$ and Matsushima K: Overproduction of Th2-specific chemokines in $\mathrm{NC} / \mathrm{Nga}$ mice exhibiting atopic dermatitis-like lesions. J Clin Invest 104: 1097-1105, 1999.
7. Hashimoto S, Nakamura K, Oyama N, Kaneko F, Tsunemi Y, Saeki $\mathrm{H}$ and Tamaki K: Macrophage-derived chemokine (MDC)/CCL22 produced by monocyte derived dendritic cells reflects the disease activity in patients with atopic dermatitis. J Dermatol Sci 44: 93-99, 2006.

8. Kozma GT, Falus A, Bojszkó A, Krikovszky D, Szabó T, Nagy A and Szalai C: Lack of association between atopic eczema/dermatitis syndrome and polymorphisms in the promoter region of RANTES and regulatory region of MCP-1. Allergy 57: $160-163,2002$.

9. Lai P, Du JR, Zhang MX, Kuang X, Li YJ, Chen YS and He Y: Aqueous extract of Gleditsia sinensis Lam. fruits improves serum and liver lipid profiles and attenuates atherosclerosis in rabbits fed a high-fat diet. J Ethnopharmacol 137: 1061-1066, 2011.

10. Lim JC, Park JH, Budesinsky M, Kasal A, Han YH, Koo BS, Lee SI and Lee DU: Antimutagenic constituents from the thorns of Gleditsia sinensis. Chem Pharm Bull (Tokyo) 53: 561-564, 2005.

11. Zhou L, Li D, Jiang W, Qin Z, Zhao S, Qiu M and Wu J: Two ellagic acid glycosides from Gleditsia sinensis Lam. with antifungal activity on Magnaporthe grisea. Nat Prod Res 21: 303-309, 2007.

12. Zhou L, Li D, Wang J, Liu Y and Wu J: Antibacterial phenolic compounds from the spines of Gleditsia sinensis Lam. Nat Prod Res 21: 283-291, 2007.

13. Li WH, Zhang XM, Tian RR, Zheng YT, Zhao WM and Qiu MH: A new anti-HIV lupane acid from Gleditsia sinensis Lam. J Asian Nat Prod Res 9: 551-555, 2007.

14. Wu J, Li J, Zhu Z, Li J, Huang G, Tang Y and Gao X: Protective effects of echinocystic acid isolated from Gleditsia sinensis Lam. against acute myocardial ischemia. Fitoterapia 81: 8-10, 2010.

15. Ha HH, Park SY, Ko WS and Kim Y: Gleditsia sinensis thorns inhibit the production of NO through NF-kappaB suppression in LPS-stimulated macrophages. J Ethnopharmacol 118: 429-434, 2008.

16. Cheng PY, Lee YM, Wu YS, Chang TW, Jin JS and Yen MH: Protective effect of baicalein against endotoxic shock in rats in vivo and in vitro. Biochem Pharmacol 73: 793-804, 2007.

17. Kundu JK and Surh YJ: Inflammation: Gearing the journey to cancer. Mutat Res 659: 15-30, 2008.

18. Gröne A: Keratinocytes and cytokines. Vet Immunol Immunopathol 88: 1-12, 2002.

19. Sebastiani S, Albanesi C, De PO, Puddu P, Cavani A and Girolomoni G: The role of chemokines in allergic contact dermatitis. Arch Dermatol Res 293: 552-559, 2002.

20. Qi XF, Kim DH, Yoon YS, Li JH, Song SB, Jin D, Huang XZ Teng YC and Lee KJ: The adenylyl cyclase-cAMP system suppresses TARC/CCL17 and MDC/CCL22 production through p38 MAPK and NF-kappaB in HaCaT keratinocytes. Mol Immunol 46: 1925-1934, 2009.

21. Saeki $\mathrm{H}$ and Tamaki $\mathrm{K}$ : Thymus and activation regulated chemokine (TARC)/CCL17 and skin diseases. J Dermatol Sci 43: 75-84, 2006.

22. Hino R, Kobayashi M, Mori T, Orimo H, Shimauchi T, Kabashima K and Tokura Y: Inhibition of T helper 2 chemokine production by narrowband ultraviolet $\mathrm{B}$ in cultured keratinocytes. Br J Dermatol 156: 830-837, 2007.

23. Appay V and Rowland-Jones SL: RANTES: A versatile and controversial chemokine. Trends Immunol 22: 83-87, 2001. 